\title{
TYPHA LAXMANNII LEPECH. THE NEW, EXPANSIVE KENOPHYTE IN POLAND: DISTRIBUTION AND TAXONOMY
}

\author{
JANUSZ BARYŁA ${ }^{1}$, EDWARD BRÓŻ², ANDRZEJ CZYLOK ${ }^{3}$, \\ AgNiESZKA MichalewSKA ${ }^{5}$, AgNIESZKA NiKEL ${ }^{4}$, MARCIN NOBIS ${ }^{5}$, \\ RENATA PIWOWARCZYK ${ }^{5}$, AGNIESZKA POLOCZEK ${ }^{5}$ \\ ${ }^{1}$ Ojców National Park \\ 32-047 Ojców, No. 13, Poland \\ 2 Department of Botany, Institute of Biology, \\ Świętokrzyska Academy \\ Świętokrzyska 15, 25-406 Kielce, Poland \\ ${ }^{3}$ Department of Biogeography and Nature Protection, \\ Faculty of Earth Sciences, University of Silesia \\ Będzińska 60, 41-200 Sosnowiec, Poland \\ ${ }^{4} \mathrm{~W}$. Szafer Institute of Botany, Polish Academy of Sciences \\ Lubicz 46, Kraków, Poland \\ ${ }^{5}$ Department of Plant Taxonomy and Phytogeography, \\ Institute of Botany, Jagiellonian University \\ Kopernika 27, 31-501 Kraków, Poland
}

(Received: July 14, 2004. Accepted: September 29, 2004)

\begin{abstract}
The paper provides data on a new antropophyte species - Typha laxmannii Lepech. which spreads throughout Poland as a hemiagriophyte. Its present distribution in Poland is given on a cartogramme map in a $10 \times 10 \mathrm{~km}$ square grid and its geographic element, population numbers and notes on habitats are provided. An identification key to 5 species of the Typha genus, two native, one new which is the topic of this paper, and two which can be expected to be discovered in Poland.
\end{abstract}

KEY WORDS: Typha laxmannii, identification key, cartogramme, Poland, kenophyte, hemiagriophyte.

\section{INTRODUCTION}

In recent years, many new kenophyte species have settled in Poland, in some cases attaining the agriophyte status of settlement (Zając, Zając, Tokarska-Guzik 1998). In some cases a species is discovered in Poland and identified by botanists, but only after many years following its arrival. Such a situation occurred with this new species of Typha laxmannii Lepech.

\section{GENERAL DISTRIBUTION AND THE CHARACTER OF RANGE}

T. laxmannii is a species belonging to the Euro-Siberian sub-element. In Europe it most likely occurs naturally only in Bulgaria, Romania and the Ukraine (with the Crimea included), and in south-western part of Russia (Cook 1980; Prokubin 1987; Schmalhausen 1897). Its Asian range is largely unknown. In Asia, the species occurs in the temperate zone, reaching in the south up to the mountains of Central Asia, northern China and Mongolia, whereas in the southwest - to Turkey and northern Iran (Krylov 1927; Komarov 1934; Davis 1984). In the south-western limit of its distribution, the species is a synanthrope and was reported from the Czech Republic (Čvančara and Šourkova 1973; Dostál 1989; Kubát 2002), Germany (Oberdorfer 1990; Haeupler and Muer 2000), France (Guinochet and de Vilmorin 1978), Slovenia (Kaligarič and Jogan 1996) and Italy (Pignatti 1982). There is still an outstanding issue of the natural occurrence of this taxon in Greece (Halacsy 1902; Hayek 1932-1933), which can only be solved by further studies. 


\section{DISTRIBUTION IN POLAND}

In Poland, Typha laxmannii was first discovered in 1988 on the Kraków-Sandomierz Upland, in a Devonian limestone quarry south of the provincial town of Kielce. The next station was discovered in 1990, in the same region, although this time some $20 \mathrm{~km}$ north-east of Kielce, and yet another in 1999 on the Silesian Upland. The search for the species conducted in the period 2000-2002 on the Małopolska Upland, yielded a number of new stations. In 2001, the taxon was found in the Beskid Niski Mts., and in 2003 it was found on several sites within the eastern part of Sandomierz basin. The species was, however, only identified as late as at the beginning of this century, by Czylok and Baryła $(2003 a, b)$. Its present distribution is illustrated in Figure 1, showing that Typha laxmannii has most of its stations in the southern Polish uplands. Definitely, further searches in certain types of sites are likely to yield more new sites. The taxon, although fairly conspicuous and easily recognizable in the field, is not often recorded and collected by botanists. It can be treated as a new species of expanding kenophyte of which the habitats indicate to it being already settled as a hemiagriophyte. This classification is based on types of habitats occupied by the species.

\section{HABITAS AND POPULATION NUMBERS}

In its native distribution, Typha laxmannii is a reed-mace fen species. It occurs in similar situations also in the areas where it is a synanthrope. In Poland, within the Małopolska Upland, almost all stations are situated upon artificial bodies of water, created by the surfacing ground waters in quarries of Devonian limestones or dolomites. Only one station is located near a pond in a village. In many cases, the patches with this new kenophyte are almost exclusively made of this single species, sometimes with admixtures of common reed community plants such as Bidens melanocarpus. In these patches, two native reedmace species ( $T$. angustifolia L. and T. latifolia L.) often occur, accompanied by such species as Equsietum palustre, E. variegatum, Puccinellia distans and others, on the edges.

The station in the Silesian Upland is located in an abandoned sand extraction site. Here, the new reedmace species is often accompanied by interesting species, such as Lycopodiella inundata and Drosera rotundifolia, depending on the prevailing moisture levels.

In all these stations $T$. laxmannii has abundant flowers and bears fruits. The population numbers are variable. The description of sites provides approximate population num-

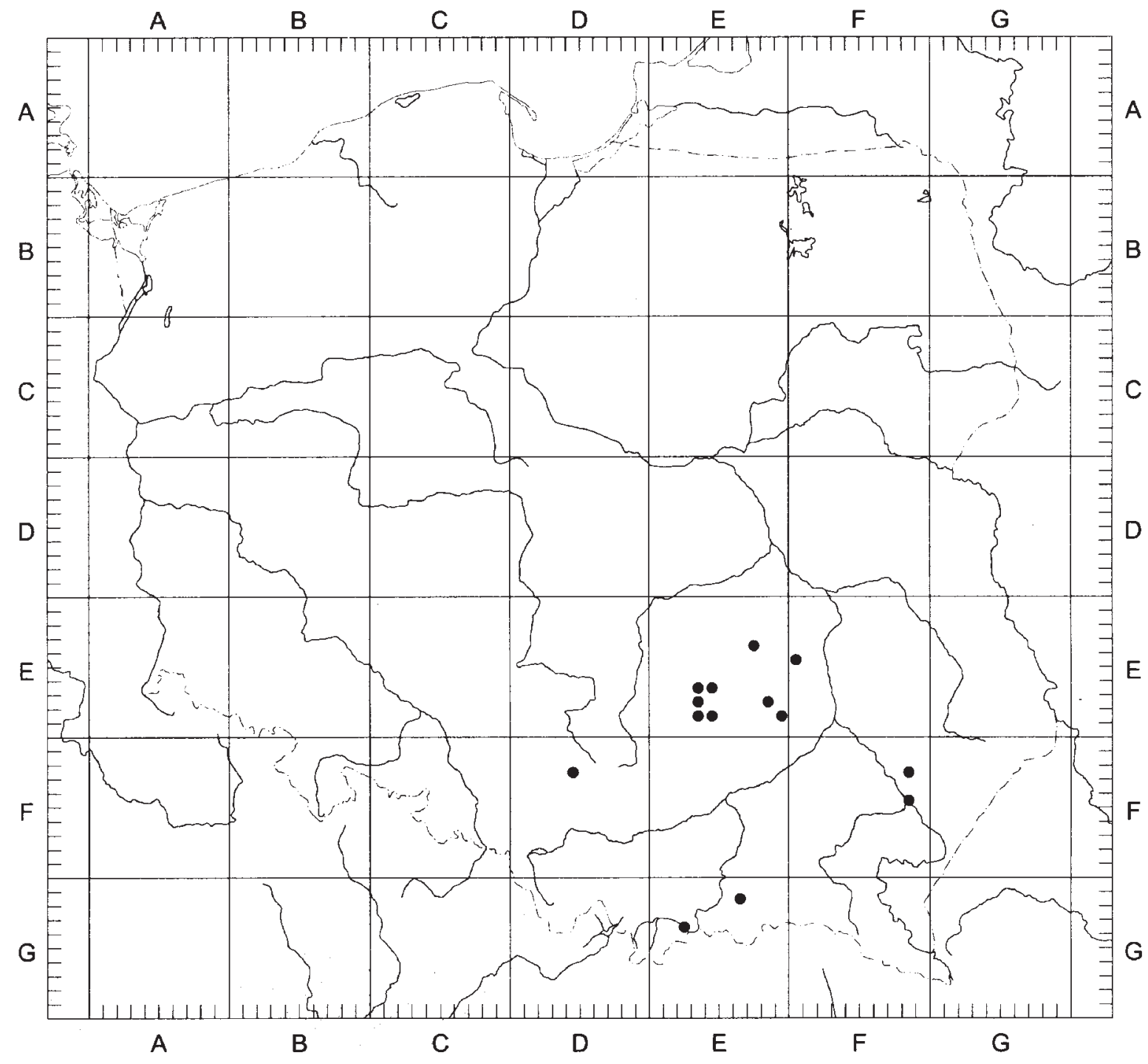

Fig. 1. Distribution of Typha laxmannii Lepech. in Poland (in ATPOL grid 10×10 km). 
bers, showing the variability from several dozen to several thousand. The observations which have been made at the Kowala-Sobków quarry since 1988 permit the conclusion, that in a dozen or so years, the population has increased significantly.

\section{TAXONOMIC NOTES}

Two native species of the Typha genus (T. angustifolia and T. latifolia) have been reported in Poland to-date. These are common throughout Poland (Zając and Zając eds 2001). At present, we have recorded the third, new species $-T$. laxmannii, which is a synathrope. It is very likely that two more species: T. minima Hoppe and T. shuttleworthii Koch can be discovered in Poland. The former is commercially cultivated and sold as a "garden-reed" species. Both these taxa are reported from areas south of Poland (Dostál 1989), although it is not clear whether they are native there or only established synathropes. Below an identification key is provided for five taxa of Typha: three of them occurring in Poland and two that can be expected to occur. As the taxonomic features used in the key are fairly evident, the identification of the reedmaces should not pose any problems, and as the key does not include additional descriptions or drawings. There are also references to other publications where these species are described and illustrated in detail (Čvančara and Šourkova 1973; Dostál 1989; Kaligarič and Jogan 1996; Kubát ed. 2002).

\section{IDENTIFICATION KEY FOR THE SPECIES OF THE TYPHA GENUS IN POLAND}

1. Below female and male inflorescences there are leaflike bracts, female part of inflorescences $1.5-4.5 \mathrm{~cm}$ long

\section{T. minima Hoppe}

$1^{*}$. Below female and male parts of inflorescences there are no leaflike bracts, female part of inflorecences larger . .2

2. Female flowers with scales

\section{T. angustifolia $\mathrm{L}$.}

$2^{*}$. Female flowers without scales ............

3. Leaves 2-4 (-7) mm wide, male part of inflorescences in a 1-6 cm distance from the female, female part of inflorescences 4-7 cm long, cylindrical, single pollen grains

\section{T. laxmannii Lepech.}

$3^{*}$. Leaves more than $7 \mathrm{~mm}$ wide, sometimes much wider, male part of inflorescences closely packed above the female ones, female part of inflorescences more than 8 $\mathrm{cm}$ long, pollen grains in tetrads . . . . . . . . . . 4

4. Leaves wider than $10 \mathrm{~mm}$, female part of inflorescences \pm almost as long as male ones, anthers $2.5-3 \mathrm{~mm}$ long

\section{T. latifolia L.}

$4 *$. Leaves 7-10 mm wide, female part of inflorescences markedly longer than male ones, anthers 1.4-2.2 mm long

T. shuttleworthii W.D.J. Koch \& Sond.

\section{CONCLUSIONS}

The above-presented kenophyte species T. laxmannii - is an established anthropophyte species in a hemiagriophyte stage. It has several dozen stations in Poland, some of them very abundant. It occupies habitats mainly in old quarries and sand pits flooded with water, where it grows within semi-natural reedswamp communities. To-date, no invasion into natural habitats has been observed. It is perhaps an even more common species in Poland, but is not distinguished by botanists from other species of the genus. Its further expansion can be expected, particularly in quarries and sand pits. The species should be monitored closely, because its possible invasion into natural plant communities could threaten the biodiversity of the latter by squeezing out native components. The pattern of stations indicates, that the prevailing area is that of the southern uplands in Poland, i.e. the area with a higher average annual temperature. It is not certain, however, whether this represents any regularity or the species can appear, as a synathrope, in other parts of Poland.

\section{LIST OF LOCALITIES}

The localities are given in the ATPOL grid (Zając 1978). Abbreviations of herbaria after Mirek et al. 1997.

DF

24 - Dąbrowa Górnicza, Kuźnica Warężyńska, sand-pit, several hundred specimens, 1999, lg. J. Baryła \& A. Czylok, KRA.

\section{EE}

37 - Wierzbica, $500 \mathrm{~m}$ NWW, chalk-pit, more than ten thousand specimens on area of $0,75 \mathrm{~km}^{2}, 2000,1 \mathrm{~g}$. M. Nobis, KRA; 63 - Kostomłoty II, Kostomłoty-Laskowa chalk-pit, near 100 specimes (20 flowering), 2002, lg. E. Bróż KTC; 64 - Zagnańsk, Zachełmie chalk-pit, in the 1990, 200 specimens, lg. E. Bróż KTC; 73 - Szczukowskie Górki, Szczukowskie Górki chalk-pit, tens specimens, 2002, lg. E. Bróż KTC; 78 - Skały near Grzegorzewice, Skała chalk-pit, several hundred specimens, 2002, lg. E. Bróż KTC; 83 - Bolechowice, Jaźwica chalk-pit, about hundred specimens, 2002, lg. E. Bróż KTC; 84 - Sitkówka-Nowiny, Trzuskawica-Kowala chalk-pit, tens specimens, 2002, 1g. E. Bróż KTC; 84 - Kowala, Kowala-Sobków chalk-pit, locality known in the 1988, 2002, now several thousand specimens, lg. E. Bróż, M. Nobis, R. Piwowarczyk KRA, KTC; 84 - Morawica, Morawica III chalkpit, tens specimens, 2002, lg. E. Bróż KTC; 89 - Piskrzyn near Iwaniska, Piskrzyn chalk-pit, tens specimens, 2002, lg. E. Bróż KTC; 89 - Wymysłów near Iwaniska, Wymysłów chalk-pit, tens specimens, 2002, lg. E. Bróż KTC.

\section{EG}

16 - Ptaszkowa, Beskid Niski, a ditch near railway, few specimes, 2002, lg. A. Poloczek, KRA; 32 - moutch of Nidziczanka to Czorsztyńskie Lake, few specimens, 2001, lg A. Nikel, KRAM.

FE

40 - Sienno, drainage pond in village, about forty specimens, 2002, lg. R. Piwowarczyk, KRA. 
FF

28 - Potok Górny, sand pit, few specimens, 2003, 1g. A. Michalewska, KRA, 48 - S from Sieniawa, sandy, and moist a ditch, tens specimens, 2003, lg. A. Michalewska \& M. Nobis, KRA; Pigany, moist sand pit near San old river-bed, 2003, several hundred specimens, lg. A. Michalewska \& M. Nobis, KRA.

\section{LITERATURE CITED}

COOK C.D.J. 1980. Typha L. In: Flora Europaea. Vol. 5 (Alsimataceae to Orchidaceae). T.G. Tutin, V.H. Heywood, N.A. Burges, D.M. Moore, D.H. Valentine. S.M. Walters, D.A. Webb (eds). Cambridge University Press, Cambridge, London, New York, New Rochelle, Melbourne, Sydney, pp. 275-276.

CZYLOK A., BARYŁA J. 2003a. Notatki florystyczne i ekologiczne z okolic Dąbrowy Górniczej i Sławkowa (Wyżyna Śląska) [Floristical and ecological notes from the vincity of Dąbrowa Górnicza and Sławków (Silesian Upland)]. Natura Silesiae Superioris 7: 11-17 (in Polish with English and German summary).

CZYLOK A., BARYŁA J. 2003b. Sukcesja roślinna w wyrobisku po piasku koło Kuźnicy Warężyńskiej [Succesion of plants in the sand-pit near Kuźnica Warężyńska]. Przyroda Górnego Śląska 31: 11-12 (in Polish).

ČVANČARA A., ŠOURKOVA M. 1973. Poznamky k rozsireni a variabilite Typha laxmannii Lepech. v Ceskoslovensku. Preslia 45: 265-275 (in Czech with German summary).

DAVIS P.H. 1984. Flora of Turkey and the East Aegean Islands. Vol. 8. University Press, Edinburgh, pp. 1-632.

DOSTÁL J. 1989. Nová květena ČSSR. Vol. 2. Academia, Praha, pp. 765-1548.

GUINOCHET M., DE VILMORIN R. 1978. Flore de France. Vol. 3. Centre national de la recherche scientifique, Paris, pp. 819-1200

HALACSY E. (de). 1902. Conspectus Florae Graecae. Vol. 2. Guilelmi Engelmann, Lipsiae, pp. 1-612.
HAYEK A. 1932-1933. Prodromus Florae penninsulae Balcanicae. Vol. 3. Verlag des Repertorimus, Berlin, pp. 1-580.

HEUPLER H., MUER T. 2000. Bildatlas der Farn- und Blütenpflanzen Deutschlands. Verlag Eugen Ulmer. Stuttgart, pp. 1-759 .

KALIGARIČ M.K., JOGAN N. 1996. Typha laxmannii Lepech., nova vrsta v flori Slovenije. Hladnika 7: 21-28 (in Slovenian with English summary).

KOMAROV W.Ł. (ed.). 1934. Flora SSSR. Vol. 1. Izd. Akademii Nauk SSSR, Leningrad, pp. 1-298 (in Russian).

KRYLOV P. 1927. Flora Zapadnoj Sibiri. Vol. 1 (PteridophytaHydrocharitaceae). Izd. Krasnoje Znamja, Tonsk, pp. 1-138 (in Russian).

KUBÁT K. (ed.) 2002. Klíč ke květeně České republiky. Academia, Praha, pp. 927 (in Czech).

MIREK Z., MUSIAŁ L., WÓJCICKI J.J. 1997. Polish Herbaria. Polish Bot. Stud. Guidebook Series 18: 3-116.

OBERDORFER E. 1990. Pflanzensoziologische Excursions Flora. Eugen Ulmer Verlag, Stuttgart, pp. 1050.

PIGNATTI S. 1982. Flora d'Italia. Vol. 3. Edagricole, Bologna, pp. 1-780 (in Italian).

PROKUBIN JU.N. (ed). 1987. Opredelitel' wysszich rastenij Ukrainy. Kijev, Naukova Dumka, pp. 456 (in Russian).

SCHMALHAUSEN J. 1897. Flora Srednej i Jużnoj Rossij. Vol. 2. Kijev', pp. XIV, 752. (in Russian).

ZAJAC A. 1978. Atlas of distribution of vascular plants in Poland (ATPOL). Taxon 27 (5/6): 481-484.

ZAJĄC A., ZAJĄC M., TOKARSKA-GUZIK B. 1998. Kenophytes in the flora of Poland: list, status and origin. Phytocoenosis. Supplementum Cartographiae Geobotanice 9: 107-116.

ZAJĄC A., ZAJĄC M. (eds). 2001. Atlas rozmieszczenia roślin naczyniowych w Polsce. Distribution Atlas of Vascular Plants in Poland. Nakładem Pracowni Chrologii Komputerowej Instytutu Botaniki UJ, Kraków p. XII + 716 (in Polish and English). 